\title{
Value Addition of Feed and Fodder by Alleviating the Antinutritional Effects of Tannins
}

\author{
T. K. Bhat • A. Kannan • Birbal Singh • \\ O. P. Sharma
}

Received: 20 January 2012/Accepted: 31 May 2013/Published online: 23 June 2013

(C) NAAS (National Academy of Agricultural Sciences) 2013

\begin{abstract}
Tannins are one of the important plant secondary metabolites having wide prevalence in the plant kingdom. They are a prominent constituent of various types of feed, fodder and agro-industrial wastes. The intake of tannins at a low level has recently been found to have some positive effects in ruminants. However, the use of tannin-rich biomass as animal feed, having high content of tannins, is limited by the antinutritional effects of tannins at this level in an animal system. A number of physical, chemical, biological and miscellaneous approaches have been developed for inactivation or removal of tannins for enhancement of the feeding value of tannin-rich biomass. However, none of the individual method is successful in total inactivation or removal of tannins without loss of nutritive value, and this limits the utilization of a vast amount of plant resource. A cohesive and an integrated detanninification strategy is required for alleviating the antinutritional effects of tannins in animals and upgrading the feeding value of tanniniferous biomass.
\end{abstract}

Keywords Tannins $\cdot$ Tanniniferous feedstuffs $\cdot$ Antinutritional effects $\cdot$ Alleviation methods $\cdot$ Value addition

\section{Introduction}

A shortage of quality feed and fodder resources has been identified as the major constraint in livestock production in the developing countries, and these countries, from time to time, experience shortage of animal feed of the conventional type [24]. Although forages, such as grasses, legumes and tree forages, and the agro-industrial byproducts are available, their utilization as animal feed and fodder is limited due to the presence of dietary antinutritional factors like tannins which affect the voluntary intake and the gastrointestinal function of the animals [195]. Great economic losses through general loss of condition, poor weight gain, inefficient production and death have been attributed to these dietary factors [195].

Tannins are present in a large number of feeds and forages and are one of the most common antinutritional factors [94,

T. K. Bhat $(\bowtie) \cdot$ A. Kannan - B. Singh - O. P. Sharma

Regional Station, Indian Veterinary Research Institute,

Palampur 176061, Himachal Pradesh, India

e-mail: tejkbhat@gmail.com
100, 193]. After lignins, tannins are the second most abundant group of plant phenolics. They are considered as plant secondary metabolites as they are not involved in metabolic pathways [137]. Tannins are water-soluble compounds, with molecular weight generally ranging from 0.5 to $3 \mathrm{kDa}$, and can be classified into two major groups: hydrolysable tannins and condensed tannins, also known as proanthocyanidins [217]. A group which occupies an intermediate position in the tannin hierarchy is the family of catechin tannins combining elements of hydrolysable and condensed tannins [28]. These tannins are quite common in tropical shrub legumes $[134,140]$ and tea leaves [60].

During the past decade, there has been a changing perception of the antinutritional effects of tannins in animals, especially ruminants [194]. The intake of tannins, particularly condensed tannins, at low to moderate level (2-4\% of dry matter) in the feed of animals has been observed to have a beneficial effect on protein metabolism in ruminants, reduce bloat and have an anthelmintic effect on gastrointestinal parasites [141, 158, 177].

This paper reviews the current status of knowledge on tannins, their antinutritional effects at a high level of intake 
( $>5 \%$ of dry matter) and discusses the various methods available for negating their harmful effects for enhancement of feeding value of tanniniferous feed and fodder.

\section{Tannins in Feed and Fodder}

\section{Prevalence and Nature of Tannins}

Tannins are widely prevalent in plant material, in both leguminous and non-leguminous species, and most of the species of forage and browse legumes used as ruminant feed, contain tannins [138]. Makkar [93] listed the tanninpolyphenolic contents of 62 species of trees and shrubs from India. The list included important fodder species such as Calliandra calothyrsus, Ficus spp., Gliricidia sepium, Leucaena leucocephala and various species of Acacia, Albizia, Prosopis and Quercus. Tannins are not restricted to tropical feeds as lotus, sainfoin, and other temperate species have also been found to contain condensed tannins [211]. Thus, the occurrence of tannins is not restricted to particular limited class of plants or climatic zones. They are, therefore, likely to be consumed in all agricultural systems where trees and shrubs are used as livestock feed. Besides trees and shrubs, tannins are present in a number of agro-industrial by-products, including various seeds and seed cakes, which might be useful as feeds [93]. Cassava leaves, a potentially useful forage, sorghum grain and stover also contain tannins [135, 170]. Therefore, several crop residues and by-products of considerable importance as livestock feeds in developing countries contain tannins.

Hydrolysable tannins (HTs) are abundant in leaves, fruits, pods and galls of dicotyledons such as oak, chestnut and other species, whereas condensed tannins (CTs) are even more widespread [84]. Some species contain both types of tannins. In the living plant cells, molecules of both HTs and CTs are localized in vacuoles within the cell and are believed to be only released into the cytoplasm when cell damage or death occurs. The tannin content of plants is affected by plant species, genotype and stage of growth and may vary with plant part (leaf, stem, inflorescence, seed), season of growth and other specific environmental factors such as temperature, rainfall, cutting and defoliation by grazing herbivores including insects. A major characteristic is their propensity to form chemical complexes not only with proteins but also with many other compounds like polysaccharides, nucleic acids, steroids, alkaloids and saponins [86, 137]. Robbins et al. [175] suggested that the plant defensive nature of tannins as digestion inhibitors or toxins in animals is dependent on the molecular characteristics of the tannin as it interacts with the physiological capability of the animal.

The structures of HTs are based on a hexose (usually glucose) linked to a number of gallic acid or modified gallic acid units. The variability of HTs is derived from the type of sugar, the number of gallic acid units and the number and types of linkages between the gallic acid units. CTs are flavan-3-ol oligomers carrying varying degrees of oxidation on the $\mathrm{A}$ and $\mathrm{C}$ rings of each monomer and that the chirality of C-4, where linkage of monomers occurs, and $\mathrm{C}-3$ open up the possibilities for considerable structural variability. CTs, as compared to HTs, are more stable and less susceptible to hydrolysis, and the type and position of the inter-flavanol linkages affect the overall shape and flexibility of tannin molecule [136]. The complexation between tannin and protein is central to the biological action of tannins. Proteins with an open structure and those rich in the amino acid proline appear to have a particularly high complexation coefficient, while glycoproteins, globular proteins and those of low molecular weight have low affinities [138]. Tannins produced by different species or by the same species in different parts or at different times vary in their capability to precipitate proteins. Different HTs do exhibit structure-related protein precipitation profiles, while in CTs, molecular weight is important [85].

The affinity of tannins for the protein has been observed to increase regularly with the increase in molecular size of tannins. Both HTs and CTs form reversible insoluble complexes with proteins. The conditions under which complexation takes place has been shown to cause considerable variation in the strength of the interaction. The solubility of the tannin in water is a prime biological consideration. The relative proportions of tannin and protein can lead to very different outcomes as in many cases an excess level of protein will solubilize a precipitate. The $\mathrm{pH}$ of the system and the presence of solubilizing agents such as bile acids are able to modify the interaction between tannin and protein to a considerable degree [129]. Jones and Mangan [73] first showed that reactivity between $\mathrm{CTs}$ and forage protein was $\mathrm{pH}$-dependant, with stable complexes being formed at $\mathrm{pH} 3.5-7.5$, but the complexes dissociated and released protein at $\mathrm{pH}<3.5$. CTs reacted with forage proteins in a $\mathrm{pH}$-reversible manner, with reactivity determined by the concentration, structure and molecular weight of the CTs. The $\mathrm{pH}$ is important in governing the formation of tannin-protein complexes. Binding is particularly high at the isoelectric $\mathrm{pH}$ of the protein and is much less strong at high $\mathrm{pH}$, where the phenolic groups of the tannins are ionized [112]. Acidity may also play an important role in breaking down tanninprotein complex in the gut [137]. Ribulose bisphosphate carboxylase-oxygenase (Rubisco) enzyme, earlier known as Fraction $1(\mathrm{Fl})$ leaf protein, predominates in forages, and its digestion in the small intestine, as opposed to fermentation in the rumen, would be advantageous to ruminants since biological value of this protein exceeds that of microbial protein [117]. It has been suggested that a 
complex is formed between CTs and Rubisco protein through reversible hydrogen bonding which is stable at $\mathrm{pH}$ values between 4 and 7, but which readily dissociates on either side of this range [158]. This complex escapes fermentation in the rumen where the $\mathrm{pH}$ ranges from 5 to 7 , but dissociates on exposure to gastric $(\mathrm{pH} 2.5-3.5)$ and pancreatic ( $\mathrm{pH} \mathrm{8-9)} \mathrm{secretions.}$

\section{Importance of Tanniniferous Feeds and Forages}

Tanniniferous feeds are important to ruminants in many developing countries. However, there are few published estimates on either the quantities or proportions of such feeds in the livestock diets. Devendra [42] has noted some broad estimates of the importance of tree browses (shoots, twigs, leaves, fruits and pods of trees and shrubs), which are generally high in tannins and important in arid and semi-arid regions. In northern Africa, tannin-rich browse forms 60 to $70 \%$ of rangeland production and $40 \%$ of the total available feed; other estimates put such feeds as making up 40-50\% of the total available feed [50]. Tree leaves and pods are widely consumed by ruminants in subSaharan Africa. Gutteridge and Shelton [61] have reviewed the role of forage tree legumes, noting that at least $75 \%$ of the shrubs and trees of Africa serve as browse plants. In India, $60-70 \%$ of the forage requirements for goats are tanniniferous tree browses, with tree legumes being particularly significant [42]. Browses are particularly important in extensive livestock systems and become more important when the supply of alternative feeds is restricted such as during dry seasons and periods of drought. In Australia, mulga (Acacia aneura) is grown in stands for use as drought reserves for grazing sheep [61]. The ability of animals such as goats and camels to survive on tannin-rich browse largely explains why these animals are preferred in drought prone areas.

Tree fodder is also important in forested highland regions. The tanniniferous tree forages are particularly essential during the dry season when alternative green fodder is often not available. This broad pattern of tree leaf usage is found in the mountainous forested lands of northern India; oak tree leaves are particularly significant in the highland (approximately 1,500-4,000 m) areas during the February to April season. A study in the middle hills (900-2,000 m altitude) in eastern Nepal identified 14 major fodder tree species used principally in the winter and dry seasons (November-June) to supplement crop residues in ruminant feeds. In this region, tanniniferous tree fodder contributed over $15 \%$ of the dry matter and over $20 \%$ of the crude protein to the diet, but actual usage on individual farms varied depending on the ethnic and social group of the farmers, possible as a result of different livestock holdings and opportunities for planting trees [76, 205, 212, 223].
In the more humid tropical areas, legumes are often planted specifically for forage in extensive grazing systems and in association with crops. The leguminous trees are planted along field borders or fence lines by farmers with small-land holdings. Herbage is lopped in cut and carry systems and used as supplements to low-quality feeds such as tanniniferous crop residues. The tree fodder containing tannins is also widely used in South America, Australia and southern Africa in more extensive grazing areas. In the subhumid coastal region of Kenya, $45 \%$ of smallholder farmers used browse from fodder trees such as Calliandra calothyrsus [173]. Tanniniferous tree browses formed about $1-2 \%$ of the feed of cattle in The Gambia during the dry season, but for goats such feed may constitute $10 \%$ of the diet [173]. In humid and sub-humid lowland regions of Bolivia, beef steers at pasture with access to poor quality pasture and L. leucocephala would eat about $30 \%$ of their diets as leucaena in the dry season. Wet season consumption was somewhat lower at about $20 \%$, presumably due to the availability of more and better quality pasture. In Jamaica, goats at pasture ate at least $30 \%$ of their diets as legumes [138]. Sorghum and its by-products which are rich in tannins are widely produced, particularly in semi-arid regions. Sorghum stovers are used to feed cattle in many African and Asian countries, particularly in the dry season [138, 142]. Thus, tanniniferous feeds can be an important part of the diets of livestock in high cropping areas and not just in areas where high usage often reflects a lack of alternative feeds.

A number of feed and fodder containing different levels of tannins have been used in animal feeding trials, and variable beneficial effects on the nutrition and health of the animals have been observed. These were leaves-Acacia brevispica, A. nilotica, A. tortillis, Salix caprea and S. viminalis fed to sheep, goats and cattle $[38,44,45,114$, 121, 131, 134, 140], C. calothyrsus, Onobrychis viciifolia fed to goats, lambs and cattle [68, 108, 151, 221] carob (Ceratonia siliqua), Lespedeza cuneata, Prosopis cineraria, Quercus semecarpifolia given to goats [30, 188], Desmodium ovalifolium, Dorycnium rectum, Hedysarum coronarium, Lotus corniculatus, L. pedunculatus fed to sheep [13, 122, 150, 201, 210] and Leucaena leucocephala given to ruminants $[72,118]$. The fruits-Acacia tortillis, Dichrostachys cinerea given to goats [105, 128], honey locust (Gleditsia triacanthos) avidly eaten by sheep [31] and acorns of Quercus rotundifolia, found to be excellent for Mediterranean pigs and ruminants [34], were also used for animal feeding. The other unconventional tannin-rich feed and fodder tried were green tea (Camellia sinensis) extract for calves [70], chestnut (Castanea sativa) wood extract and tannins for cattle, pigs and lambs [56, 83, 192, 230], peanut (Arachis hypogaea) skins and tamarind (Tamarindus indica) seed husk for dairy cows [29, 218] and rapeseed (canola) meal for pigs and ruminants $[65,79]$. 


\section{Antinutritional Effects of Tannins}

There are several possible explanations for the antinutritional effects of tannins. As outlined by Fahey and Jung [49], they include the following:

1. depression in food intake

2. complexation with: (a) dietary proteins or other dietary components, (b) digestive enzymes, (c) endogenous protein resulting in a drain on the nitrogen supply

3. toxic effects elsewhere in the body after absorption

Tannins, because of their protein-binding properties, are known to be strongly astringent. They are reported to reduce palatability due to astringency $[14,119,167,171]$. The astringent nature of tannins has encouraged a view that some animals find high-tannin-containing plants unpalatable which then discourages grazing and favours plant survival and appears to be the major cause of reduced food intake in mammalian herbivores. This hypothesis has been challenged by Foley et al. [53], and it seems that astringency alone is not sufficient to explain palatability and selectivity by grazing animals. Provenza et al. [165] suggest that mammals may reject tannin-containing plants because they cause internal malaise. Severe growth depression can be a consequence of reduced feed intake and has been shown to occur in rats and chicks when fed tannin-containing diets [49].

An adaptation or tolerance to astringency, however, is apparent in some ruminants based on frequency of exposure to tannins as a normal dietary component. Saliva of browsing ruminants such as the deer contains high levels of a small glycoprotein containing large amounts of proline, glycine and glutamate/glutamine. This high-tannin-affinity protein is absent, however, in the saliva of grazing ruminants such as the cow and sheep [7]. One theory suggests that mammalian evolution of binding of tannins by salivary proline-rich proteins may be a result of dietary nitrogen limitations arising from a low nitrogen diet [113].

Tannins are generally considered inhibitory to microbial growth and reproduction $[56,120,182]$. They are not only reactive with extracellular enzymes, but may also complex with the cell wall of microorganisms [56], deprive microorganisms of substrates required for microbial growth [182], as well as inhibit oxidative phosphorylation and electron transport. Scalbert [182] and Bhat et al. [28] have reviewed the susceptibility of microbes (fungi, yeasts and bacteria) to the toxic effects of tannins, the capability of microbial adaptation to tannins through synthesis and secretion of tannin-complexing polymers, tannin-resistant enzymes, small iron-chelating compounds known as siderophores, as well as oxidation, and biodegradation of tannins. The adaptation to the toxic effects is evident in some microorganisms and may include metabolic modifications such as the secretion of a bacterial cell wall glycocalyx [56] or secretion of tannin metabolizing enzymes [153].

Tannins inhibit the activity of enzymes of rumen microbes [10, 101, 111, 116]. CTs are known to inhibit several digestive enzymes, including proteases, pectinases, amylases, cellulases, and lipases. CTs from $L$. corniculatus have been shown to inhibit extracellular endoglucanase activity of Fibrobacter succinogenes [10], and extracts of CTs from $O$. viciifolia reduced growth and proteolytic activity of Butyrivibrio fibrisolvens, Ruminobacter amylophilus and Streptococcus bovis [71]. In contrast, Prevotella ruminicola appears to produce extracellular material which may protect the organism from the effects of tannins [71]. Enzyme inhibition is believed to be caused mainly by nonspecific binding of tannins with the enzyme protein, but may also occur when tannins bind with the substrate [49]. There are many factors which may influence the extent of digestive enzyme inhibition by tannins. Included among them are the following: (1) amount of protein in the diet, (2) relative amounts of various enzymes in the diet and the order in which they are encountered, (3) formation of tannin-protein complexes prior to and following ingestion and (4) how various enzymes are affected by $\mathrm{pH}$, type of tannin and species and age of the animal [49, 63]. The in vitro experiments have shown that while only a few tannin molecules may completely inhibit a given enzyme, this enzyme can be almost completely protected by the simultaneous presence of either a different protein or tannin-binding polymers such as polyethylene glycol or polyvinyl polypyrrlidione [52].

At high concentrations ( $>5 \%$ on dry matter basis), tannins reduce intake, performance of ruminants $[9,15,17$, 172] and wool yield in sheep [164]. When tannins complex with protein in an animal's gut, they are believed to be responsible not only for growth depression, but also for low protein digestibility and increased faecal nitrogen concentrations $[44,176]$. Thus, once they have been consumed, their adverse effects, once again, seem to be related to their binding of dietary protein. There is evidence to suggest that enzymatic proteins, as well as other endogenous proteins, comprise a considerable portion of excreted nitrogen when animals are fed tannins [49]. When endogenous proteins are lost in this manner, the animal may incur a deficiency of one or more essential amino acids.

Several workers have reported acute toxicity and livestock intoxication due to intake of oak leaf tannins and tannic acid at high levels [43, 54, 58, 159, 160, 200, 228]. Besides oak leaves, negative effects and toxicity in animals due to ingestion of tannins (both HTs and CTs) have been reported in rats and sheep due to quebracho (Schinopsis 
lorentzii) wood [39, 64], in rats and chickens due to sorghum (Sorghum bicolor) seeds [8, 32], in cattle and sheep due to yellow-wood (Terminalia oblongata) leaves [51, 144], in goats due to harendong (Clidemia hirta) leaf [143], karoo (Acacia karoo) leaves [44, 75] and babool (Acacia nilotica) fruits [187, 204], in lambs due to carob (Ceratonia siliqua) pulp [162], in livestock due to sal seed feeding [148], and in sheep due to supplejack (Ventilago viminalis) feeding [166].

HTs toxicity is most often associated with consumption of high levels of oak, Terminalia oblongata and Clidemia hirta leaves. Oak leaf poisoning in cattle has been reported from India [58, 88, 147], USA [78, 160], Slovakia [18], South Africa [149], China [186], Israel [224] and Spain [43, 159]. The consumption of Terminalia oblongata and Clidemia hirta leaves has been reported to cause hepatotoxicity and nephrotoxicity in cattle and sheep [51, 143]. The study of the antinutritional effects of tannins is complicated by their great structural diversity. The perception is still prevalent that HTs are more toxic than CTs. However, CTs which are considered non-toxic as they are not absorbed are associated with gastrointestinal lesions of the mucosa [171]. HTs hold the potential for toxicity as a result of consumption by ruminants and their degradation by ruminal microbes to produce pyrogallol, a hepatotoxin and nephrotoxin [160, 171].

Garg et al. [58] reported anorexia, severe constipation, and brisket oedema of cattle suffering from blue jack oak (Quercus incana) leaf poisoning as a result of immature leaf consumption. Faeces were reported as hard and pelleted, as well as blood- and mucous-coated. Cattle had nephrotoxicity and heptatotoxicity. They also reported depressed blood haemoglobin, as well as elevated serum bilirubin, urea nitrogen and creatine, along with hypocalcaemia, and increased serum lactate dehydrogenase, aspartate aminotransferase and alkaline phosphatase activity. Mortality was reported in $75 \%$ of affected calves. Plumlee et al. [160] reported proteinuria, haematuria, glucosuria, as well as blood urea nitrogen and creatinine increases at 3, 4, 5 and 6 days following oak leaf ingestion, respectively. The ingestion of young oak (Quercus pyrenaica) leaves by cattle triggered a critical reduction in fermentation activity of rumen concomitantly with an acute oak tannin toxicosis [43]. Perez et al. [159] studied the clinical and pathological changes associated with poisoning in cattle due to ingestion of young oak ( $Q$. pyrenaica) leaves. The clinicopathological findings included slight proteinuria, a marked increase in serum creatinine and blood urea nitrogen and other clinical signs consistent with renal failure. At necropsy, animals showed gastrointestinal ulcers and kidney tubular necrosis. Spier et al. [200] reported successful treatment of acute oak toxicosis in one calf as a result of diuretic administration and electrolyte/fluid replacement.
The effects of tannins on nutrient digestibility are not only thought to be the result of their interactions with protein and carbohydrates, but the result of the influence of tannins on overall rumen physiology [56]. Primarily, they affect rumen physiology as a result of enzyme inhibition and their direct effects on growth and morphology of rumen microbes. Tannins have also been suggested to affect gas and volatile fatty acid production in the rumen [56]. Smart et al. [198] first identified the presence of a Sericea lespedeza (Lespedeza cuneata) leaf extract that inhibited enzymatic hydrolysis of cellulose by cellulase. This was later supported by Lyford et al. [92] who suggested the compound of interest in the S. lespedeza extract to be a polyphenolic leucoanthocyanin-like compound of high molecular weight. Likewise, researchers reported that cellulase inhibition was proportional to the concentration of compound of interest in the extract [92]. Makkar et al. [101] reported decreased in vivo activity of urease, carboxymethylcellulase, glutamate dehydrogenase, glutamate ammonia ligase, as well as alanine aminotransferase as a result of ruminal incubation of tannin-containing leaf extract of blue jack oak (Quercus incana). Makkar et al. [101] also reported increased inhibition of hydrolytic enzymes (urease, protease and carboxycellulase), ammonia-assimilating enzymes, as well as alanine aminotransferase and aspartate aminotransferase due to addition of increasing amounts of tannin-containing leaf extract of blue jack oak to rumen fluid in vitro. This effect was not seen with extracts of Celtis australis leaves containing very low tannin levels. However, blue jack oak leaf extract had no effect on glutamate ammonia ligase inhibition.

The antinutritional effects of tannins present in some grains, pods and legumes (forages, trees and shrubs) are listed in Table 1. These antinutritional effects are not uniform but vary due to variation in tannin chemistry and between the animal species [84].

\section{Alleviation of Antinutritional Effects of Tannins}

An array of treatments and feeding methods has been developed to overcome the negative effects of high content of tannins ( $>5 \%$ of dry matter) in temperate and tropical forages in order to improve the nutritive value of these feeds. The methods are based on the knowledge that tannins are water-soluble polymers, which form complexes, essentially with proteins [138]. These complexes are broken under conditions of high acidity $(\mathrm{pH}<3.5)$ or high alkalinity $(\mathrm{pH}>7.5)$. The methods have mostly been developed at the laboratory level and tested in animal experimental trials. The technology developed could be scaled up for pilot and small-scale industries level. The approaches, which are aimed at inactivation or removal of 
Table 1 Tanniniferous feed and forages and their antinutritional effects

\begin{tabular}{|c|c|c|c|c|}
\hline Plant source & $\begin{array}{l}\text { Type of } \\
\text { Tannin }\end{array}$ & Animal & Effect & Reference \\
\hline Sorghum bicolor (grain) & $\mathrm{CT}$ & Monogastrics & Weight loss: lower dry matter intake & Asquith and Butler [6] \\
\hline (silage) & $\mathrm{CT}$ & Sheep & $\begin{array}{l}\text { Depressed digestion of crude fibre; less } \\
\text { microbial activity in the rumen }\end{array}$ & Ben-Ghedalia and Tagari [25] \\
\hline Abizzia chinensis (leaves) & $\mathrm{CT}$ & Goat & Reduced in sacco nitrogen digestibility & Ahn et al. [1] \\
\hline Acacia nilotica (leaves) & HT & Sheep & $\begin{array}{l}\text { Precipitation of leaf proteins: inhibition of } \\
\text { rumen fermentation }\end{array}$ & Mueller-Harvey et al. [139] \\
\hline A. aneura (leaves) & HT & Sheep & Inhibition of rumen fermentation & Pritchard et al. [164] \\
\hline Bauhinia variegata (leaves) & $\mathrm{CT}$ & Cattle & Reduced in sacco organic matter loss & Makkar et al. [103] \\
\hline Caliandra calothyrsus (leaves) & $\mathrm{CT}$ & Goat & Reduced in sacco nitrogen & Ahn et al. [1] \\
\hline Ceratonia siliqua (leaves) & $\mathrm{CT}$ & Goat & Reduced protein digestibility & Silanikove et al. $[189,190]$ \\
\hline Eugenia jambolana (leaves) & HT & Goat & Reduced feed intake, loss in weight & Panda et al. [156] \\
\hline Larrea tridentata (leaves) & $\mathrm{CT}$ & Goat & $\begin{array}{l}\text { Reduction in feed intake, digestibility and } \\
\text { nitrogen retention }\end{array}$ & Holechek et al. [66] \\
\hline Quercus gambelii (leaves) & $\mathrm{CT}$ & Goat & $\begin{array}{l}\text { Reduced digestibility of cellular constituents } \\
\text { and increased faecal nitrogen }\end{array}$ & Nastis and Malechek [145] \\
\hline Q. grises (leaves) & $\mathrm{CT}$ & Goat & $\begin{array}{l}\text { Reduction in feed intake digestibility and } \\
\text { nitrogen retention }\end{array}$ & Holechek et al. [66] \\
\hline Q. incana (leaves) & HT & Cattle & Reduced organic matter digestibility & Makkar et al. [103] \\
\hline Q. calliprinos (leaves) & HT & Cattle & Anorexia, constipation, wasting, dullness, nephrosis & Yeruham et al. [224] \\
\hline \multirow[t]{2}{*}{ Q. pyrenaica (leaves) } & HT & Cattle & Reduction in rumen fermentation activity & Doce et al. [43] \\
\hline & HT & Cattle & $\begin{array}{l}\text { Proteinuria, elevated serum creatinine } \\
\text { and blood urea nitrogen }\end{array}$ & Perez et al. [159] \\
\hline Q. robur (leaves) & HT & Cattle & Inhibition of ruminal enzyme activity & Kumar and Vaithiyanathan, [86] \\
\hline \multirow[t]{2}{*}{ Robinia pseudoacacia (leaves) } & \multirow[t]{2}{*}{$\mathrm{CT}$} & Sheep & $\begin{array}{l}\text { Reduced protein digestibility, reduced feed intake } \\
\text { and negative acid detergent fibre digestibility }\end{array}$ & Ayers et al. [9] \\
\hline & & Rabbit & Decreased wool production and nitrogen retention & Singh and Negi, [193] \\
\hline Leucaena leucocephala (leaves) & $\mathrm{HT}, \mathrm{CT}$ & Goat & Inhibits digestibility & Hove et al. [68] \\
\hline Salix tetrasperma (leaves) & $\mathrm{CT}$ & Cattle & Reduced organic matter loss in sacco & Makkar et al. [103] \\
\hline Terminalia oblongata (leaves) & HT & Sheep & $\begin{array}{l}\text { Reduction in feed intake, toxicity but no effect } \\
\text { upon digestibility }\end{array}$ & McSweeney et al. [119] \\
\hline Lespedeza cuneata (leaves) & $\mathrm{CT}$ & Cattle & Inhibits rumen fermentation & Windham et al. [222] \\
\hline \multirow[t]{3}{*}{ Ceratonia siliqua (carob pods) } & \multirow[t]{3}{*}{ HT } & Monogastrics, & Depression of growth & Tamir and Alumot [203] \\
\hline & & Chickens & Depression of growth & Joslyn et al. [74] \\
\hline & & Ruminants & Inhibition of rumen fermentation & Haddock et al. [62] \\
\hline Vicia faba (faba beans) & $\mathrm{CT}$ & Chickens & $\begin{array}{l}\text { Decreased feed intake and weight gain; decreased } \\
\text { retention of protein and calcium }\end{array}$ & Marquardt and Ward [109] \\
\hline Shorea robusta (salseed) & HT & Chickens & Depressed growth and feed conversion & Zombade et al. [229] \\
\hline
\end{tabular}

tannins from tanniniferous feed and fodder resources, are categorized as follows:

\section{Physical Methods}

A number of physical treatments from chopping to storage, alone or in combination, and with varying effect have been tried for detannification of tannin-rich feed and fodder. These treatments are as follows:

\section{Chopping}

It reduces the tannin content by increasing the contact of tannins with plant phenolic oxidases, which causes their oxidation [22, 104, 220]. 
Grinding

It increases surface area, facilitates contact between plant phenolic oxidases and tannins and may decrease tannin level [106, 209].

\section{Drying}

The drying of mature oak leaves under different conditions $\left(90{ }^{\circ} \mathrm{C}\right.$ for $24 \mathrm{~h}, 60{ }^{\circ} \mathrm{C}$ for $48 \mathrm{~h}$, shade drying for 24,48 and $72 \mathrm{~h}$ and sun drying for 24 and $48 \mathrm{~h}$ ) had no effect on the levels of total phenols, CTs, protein precipitation capacity, degree of polymerization, specific activity of tannins and bound CTs [96]. On the other hand, drying at $90{ }^{\circ} \mathrm{C}$ for $24 \mathrm{~h}$ decreased tannin content in cassava and leucaena leaves [209]. One of the reasons for this difference was found to be different level of moisture in these leaves. Cassava and leucaena leaves had about $65 \%$ moisture, whereas oak leaves had $40 \%$. The increase in moisture of oak leaves followed by the heat treatment decreased tannin levels [96]. Ben Salem et al. [22] reported sun drying was more efficient than shade drying in reducing levels of CTs in acacia foliage.

Similarly, removal of water from leucaena leaves by lyophilization also decreased the extent of tannin inactivation by the heat treatment [96]. The steaming or autoclaving $\left(1.05 \mathrm{~kg} / \mathrm{cm}^{2}\right)$ for 10 or $20 \mathrm{~min}$ of fresh oak leaves did not decrease the level of total phenols, CTs, ellagitannin and protein precipitation capacity [98]. At a 1:2 (w/v) ratio of dry ground leaves and water, steaming and autoclaving for $10 \mathrm{~min}$ reduced protein precipitation capacity by 25 and $53 \%$, respectively. The increase in treatment time did not increase the reduction in tannin. The in sacco dry matter digestibility increased marginally (from 24 to $27 \%$ ) on steaming or autoclaving [98].

The above drying conditions do not appear to hold promise for inactivation of tannins in oak leaves, but may be effective for feedstuffs having higher moisture content [209].

\section{Storage}

A number of workers have reported the decrease in tannins due to storage [22, 178, 209]. The rate and extent of decrease in both total phenols and CTs were highest at $37{ }^{\circ} \mathrm{C}$, followed by $50{ }^{\circ} \mathrm{C}$ and room temperature, on storage of whole fresh leaves containing $40 \%$ moisture [104]. The storage of chopped fresh leaves (40\% moisture) at $37{ }^{\circ} \mathrm{C}$ increased the rate of inactivation of total phenols and CTs. The change in protein precipitation capacity was also similar to that for total phenols or CTs. The inactivation of tannins during storage was due to their polymerization to higher "inert" polymers [96, 104].

The chopping of fresh leaves and then storage can be of practical use to the farmer as it requires only a minor change in normal farm practices. The leaves instead of being fed on the day they are lopped are only to be chopped and stored for about 5-10 days before feeding.

\section{Chemical Methods}

The treatment with various chemicals under alkaline conditions led to a decrease in tannin content and activity up to $90 \%$ in agro-industrial by-products and tree leaves. However, a major disadvantage of the chemical treatments is the loss of soluble nutrients, for which methods have to be devised to minimize the loss during chemical treatment. Moreover, a method has to be standardized for each tanniniferous feed and fodder resource. The various methods of chemical treatment are as follows:

\section{Ferrous Sulphate}

It is a tannin-complexing agent, and at $0.015 \mathrm{M}$ concentration reduces tannins by $85 \%$. Ferrous sulphate is known to form complex with tannins and the increase in the degree of polymerization in the treated material could be due to binding of phenolics through ferrous ions [41, 104].

\section{Urea Treatment}

Urea is the preferred alkali for treatment due to its low cost and ease of availability and handling [77, 179]. The extra nitrogen supplied by urea increases the crude protein concentration of crop residues [115]. The destabilization of tannin-protein complexes at various urea levels (2-8\%) with satisfactory results (72-89\% decrease in tannins) has been reported by various workers [22, 95, 178, 209]. The factor responsible for increased tannin inactivation observed on urea addition could be the higher $\mathrm{pH}$ caused [95] by evolution of ammonia from urea (urea-ammoniation). At $4 \%$ urea level in fresh leaves (moisture adjusted to $55 \%, 30{ }^{\circ} \mathrm{C}$ ), the reduction in total phenol and CTs was 88 and $100 \%$, respectively, on day 10 . The in sacco dry matter digestibility did not decrease up to day 5 . Thereafter, a decrease in the dry matter digestibility was observed. The decrease in the values of total phenol, CTs and protein precipitation capacity at day 1 were 55, 77 and $65 \%$, respectively, and 72,89 and $83 \%$, respectively, at day 5 [104]. The wide spread use of urea for tannin inactivation and improvement of tannin-rich feed and fodder has lagged 
due to lack of farmer's awareness, which has hindered the realization of the potential of this method [24].

\section{Oxidizing Agents}

Potassium permanganate $(0.03 \mathrm{M})$ and potassium dichromate $(0.02 \mathrm{M})$ decrease tannin level by about $95 \%$ [99]. These oxidizing agents convert tannins to quinones, which are not capable of forming complexes with proteins and can be used for large scale removal of tannins from tanniniferous feeds because of their low cost [100]. These reagents are simple to use and do not require any complex equipment. Moreover, potassium permanganate is easily available in villages in the developing countries as it is generally used for water purification and hence farmers can use this chemical for removal of tannins from tannin-rich feedstuffs.

\section{Alkaline Treatments}

The alkalis like sodium hydroxide, sodium carbonate and sodium bicarbonate act by oxidation of phenolics at higher $\mathrm{pH}[96,99]$. Sodium hydroxide $(0.05 \mathrm{M})$ is most effective, followed by sodium carbonate $(0.05 \mathrm{M})$ and sodium bicarbonate $(0.1 \mathrm{M})$. The reduction in tannins in oak leaves using these alkalis ranged between 70 and $90 \%$ [96]. The alkaline treatment with calcium hydroxide can be very effective in preventing the toxic or antinutritional effects of tannins. The calcium hydroxide treatment reduced the concentrations of extractable tannin by as much as $92 \%$ in Clidemia hirta leaves [143], Albizia procera [2] and Acacia villosa [220].

Some agro-industrial by-products (seeds of Acacia nilotica, Mangifera indica and Tamarindus indica) and oak leaves were also detanninified by using hydrogen peroxide (a strong oxidizing agent) in the presence of sodium hydroxide. The decrease in tannin content was as high as $99 \%$ [95].

\section{Wood Ash}

Wood ash, a source of alkali potentially available to farmers, is effective in reducing tannin content. The $\mathrm{pH}$ of wood ash is alkaline, and it has tannin-precipitating activity. The inactivation of tannins is caused by high pHmediated oxidation of tannins [97]. Wood ash at various levels (1-24\%) has been evaluated by different workers [22, 23, 87, 97, 199]. A $10 \%$ solution of oak wood ash and pine wood ash decreased the content of total phenols, CTs and protein precipitation capacity in oak leaves by 66,80 , $75 \%$ and $69,85,80 \%$, respectively [97]. The higher effectiveness of pine wood ash was attributed to a higher level of alkalis in the pine wood ash $(\mathrm{pH}$ value of $10 \%$ ash solution of pine wood and oak wood was 11.3 and 10.5, respectively). Kyarisiima et al. [87] reported that treatment of high-tannin sorghum with $5 \%$ wood ash extract was effective in reducing the tannin level and improved its nutritive value. Ben Salem et al. [22] observed that wood ash treatment was a cost-effective way to deactivate tannins in the foliage of Acacia cyanophylla, which improved digestion of this foliage in sheep. Wood ash solutions have also been used traditionally for treatment of high-tannincontaining sorghum and millet for human consumption. The use of wood ash, a cheap source of alkali, holds potential for detanninification of tannin-rich feedstuffs. However, as this treatment also removes nutrients, its overall effectiveness is unclear and the method has to be validated by more animal experimental studies [23, 104, 199].

\section{Treatment with Tannin-Binding Polymers}

Tannin-binding agents like polyethylene glycol (PEG) and polyvinyl polypyrrolidone (PVPP) have been widely used as research tools to investigate the in vivo and in vitro effects of tannins [196]. Both compounds are commercially available in a range of molecular weights. The lower molecular weight polymers of PEG and PVPP are highly water soluble, bind strongly to tannins and can reduce their antinutritional or toxic effects in vitro and in vivo in rats, rabbits and sheep [107]. PEG is more effective at binding tannins than PVPP [138]. The benefits from the use of PEG as tannin-inactivating agent are well documented. PEG is an inert and unabsorbed molecule that can form a stable complex with tannins, preventing the binding between tannins and protein [40]. Therefore, PEG releases forage proteins from tannin-protein complexes and improves their nutritional value leading to improved animal performance.

Tannins have higher affinity to PEG than proteins. The incorporation of PEG (molecular weight 4,000 or 6,000) has been shown to have beneficial effects in monogastrics [5, 67, 110, 169, 226, 227]. It has, however, both beneficial and adverse effects in ruminants. The incorporation of PEG in the diet has beneficial effects, particularly for tanniniferous feeds having of 5-10\% content of CTs [12, 19, 20, 86, 164, 188, 190, 191, 201, 225]. The PEG-inactivation of tannins increases voluntary feed intake, availability of nutrients and decreases microbial inhibition in degrading the tanniniferous feeds, which in turn increases the performance of animal. However, at low to moderate levels of CT (2-4\% of dry matter), addition of PEG to tanniniferous forages cause adverse effects. The addition of PEG to $L$. corniculatus containing 2-4\% CTs, decreased wool growth, weight gain [213, 214], reproduction [16] and milk yield [215]. This was attributed to substantially lower absorption of amino acids from the intestine due to increased protein digestibility in the rumen. The adverse 
effects of depressed voluntary feed intake and digestibility of nitrogen, organic matter, neutral detergent fibre and acid detergent fibre have also been reported [59, 86, 151, 154] in sheep fed on diets supplemented with PEG-treated leaves containing low to moderate levels of tannins. Krebs et al. [82] also did not observe any improvement in feed intake, nitrogen balance and rumen metabolism in sheep fed Acacia saligna foliage supplemented with PEG-4000 or 6000 .

Thus treatment with tannin-binding agents can be highly effective in overcoming the negative effects of tannins leading to improved animal performance. However, their effects can be variable which may relate to the nature and level of the tannins and the tannin-feedstuff complexes which are formed. The use of PEG for detannification of animal feeds has been observed to be successful in most of the experiments, but field application has hardly been done due to unfavourable cost-benefit ratio [22]. The price of such chemicals in developing countries would depend very much on local circumstances for carrying out an analysis of either the costs or the benefits. A commercial tanninbinding product called "Browse Plus", which contains PEG-4000, PVPP, calcium hydroxide and an emulsifier, has been marketed so far only in Zimbabwe (Africa) by "Agricura" [180]. The product is added to drinking water mainly for the consumption of cattle at a dosage rate of 1-3 $\mathrm{g}$ of product per livestock unit per day [146]. The product is said to have beneficial effects on cattle particularly during a period of drought, when presumably hightannin browses are an important component of the diet. The cattle which normally did not feed on high-tannin browses, reportedly consumed such browses when supplemented with "Browse Plus", and farmers reported increased feed intake and better animal condition [146]. There is, however, a lack of data from properly designed scientific trials on the benefits of the product [138]. It is said that low-cost grades of PEG can be used as feed supplements and that different costs of different grades may account for the diverse opinions as to the cost of treatment. It is also notable that the supplementation level with "Browse Plus" is very much less than that used experimentally when the objective is to overcome all the effects of the tannins. A less ambitious improvement with lower levels of supplementation may be more appropriate commercially. A cocktail of active ingredients, which is apparently the case in "Browse Plus", may be more effective than supplementation with PEG alone.

Charcoal has been advocated as an alternative to reagents like alkalis, oxidizing agents and PEG whose high cost limits their use in practice, and in some cases, their utilization could contribute to environmental pollution. Charcoal as a powder or as tablets has been widely used among humans for centuries to cure indigestion and, more importantly, as an antidote to detoxify poisons. It is also used as an antidote in veterinary medicine [37]. Mturi [132, 133] suggested that the habit of eating wood charcoal by the Zanzibar red colobus monkey (Procolobus kirkii), which consumes a diet of foliages containing high levels of phenolic material, is known to reduce or eliminate such toxicity by binding part of the phenolic compounds to the charcoal, thus preventing their gastrointestinal absorption. Charcoal has also been used in the diets for livestock to reduce antinutritional effects of secondary compounds in feeds. According to Poage et al. [161], lambs fed bitterweed (Hymenoxys odorata) alone, consumed considerably less than lambs that received bitterweed with activated charcoal, and higher doses of activated charcoal resulted in higher consumption of bitterweed. The effects of charcoal on elimination of harmful substances are reported to be due to the adsorption of a wide range of compounds such as phenols, alkaloids and salicylates [11, 161, 202].

\section{Biological Methods}

\section{Solid-State Fermentation}

Concerted efforts are in progress worldwide to improve tannin-rich feed and fodder by biodegradation of their tannins by microbial strains which are known to be strong tannin degraders. The attention has been mainly focused on fungal detannification, and recently, there have been endeavours to utilize the tannin-degrading activity of different fungi for detannification of tannin-rich biomass. These are detannification of oak leaves by the fungus Sporotrichum pulverulentum [102], biodegradation of tannins in Sericea lespedeza (Lespedeza cuneata) by the white rot fungi Ceriporiopsis subvermispora and Cyathus stercoreus [57] and reduction in tannins in canola meal by an enzyme preparation from a white rot fungus Trametes versicolor [89]. A fungus identified as Aspergillus niger van Tieghem having tannin-protein complex-degrading activity was isolated from the faeces of hill cattle by Bhat et al. [26, 27]. This fungus which is a prolific degrader of tannins has high tannase activity [184] and has been tried to upgrade feed value of a tannin-rich tree fodder, Robinia pseudoacacia [168]. Recently, a tannase-producing bacterial strain Enterobacter ludwigii has been isolated from the rumen of migratory goats exposed to tannin-rich browse and may be of use for reducing tannin toxicity in these animals [197]. The enzyme tannase, alone or in combination with other hydrolytic enzymes like phytase and $\beta$ galactosidase, has been tried for the enhancement of the feed value of various foodstuffs [46-48, 183, 208].

The solid-state fermentation approach has not become popular due to loss of cell solubles which are consumed by 
the fungi for their growth. The loss of cell solubles may be prevented by adding an energy source to the fermentable biomass. Further work is required for isolating fungal strains capable of preferentially degrading tannins with minimum loss of dry matter and digestible material.

\section{Direct-Fed Microbials}

The introduction of tannin-tolerant microbes into the rumen of an animal through one or more inoculations of bacterial cultures may be beneficial in developing a system to improve the productivity of ruminants consuming hightannin forages or diets, especially in the tropics. Ruminal microbes that are resistant to high levels of tannins, either singly or in a consortium, may constitute a unique part of this response. There is little and intermittent information on the use of live microbial cultures (direct-fed microbials) for the detannification and utilization of tannin-rich feed and forages. Miller et al. [125], on the basis of their preliminary results, were the first to suggest that ruminal microorganisms from animals adapted to high-tannin diets may be potentially transferable to non-adapted ruminants to improve crude protein digestion of high-tannin diets. The potential of this approach, using an inoculum of a single bacterial species, seemed promising. However, the results of their later work indicated that a consortium of bacteria, rather than a single species, may be required to improve the digestibility of forages or diets that contain high levels of tannins [126, 127]. Moreover, a longer and more detailed study involving a larger number of animals would be necessary to confirm these results. Molina et al. [130] reported that the inoculation of a tannin-tolerant bacterial isolate did not improve dry matter or crude protein digestibility of sheep consuming a diet containing $29.5 \%$ peanut skins. However, even with the small number of animals in their study, they did see a positive effect in the crude protein balance in animals receiving the laboratorycultured live inoculum. No post-inoculation effects were detected in animal performance, but the presence or absence of the inoculated bacteria in the rumen of the animals was not studied.

Recently, Chaudhary et al. [36] have shown that the feeding of live culture of a tannin-degrading isolate as a direct-fed microbial to goats fed tannin-rich pakar (Ficus infectoria) leaves did not show any effect on the rumen fermentation pattern viz. $\mathrm{pH}$, production of ammonia nitrogen, trichloroacetic acid-precipitable nitrogen, and activities of carboxymethylcellulase, xylanase, avicelase and protease. The population of rumen protozoa, total bacteria and fungi were similar in all the three groups, whereas tannin-degrading/tolerating bacteria were higher in the live isolate-fed group. The dry matter intake and digestibility of nutrients were also not influenced by feeding of the direct-fed microbial. The average live weight gain and feed conversion efficiency were also not affected due to the feeding of direct-fed microbial to the kids given $F$. infectoria leaves as the main roughage source. The feeding of the bacterial isolate did not have any effect on the nutrient utilization, rumen fermentation or growth performance in goats.

All the direct-fed microbial studies have been done using a live inoculum of a single bacterial species. This again underscores the importance of using a consortium of tannin-degrading bacteria, rather than a single species, for a synergistic and effective utilization of tanniniferous feed and forages.

\section{Supplementation}

The live weight losses associated with feeding CT-rich mulga (Acacia aneura) to livestock during drought periods in Australia have traditionally been overcome with mineral supplements. These may assist in the detoxification process and also provide additional nutrients to rumen microorganisms, as mulga tannins are known to reduce protein digestibility [91]. The addition of methionine and choline to chick diets alleviated the toxicity of tannic acid and also the toxicity of CTs or possibly the low molecular weight phenolics in sorghum [33], presumably because they functioned as methyl donors in the detoxification process and facilitated the excretion of compounds such as 4-Omethyl gallic acid [35]. However, the addition of methionine did not overcome the toxic effects of faba bean tannins in chick diets [216]. These differences between sorghum and faba bean diets have not been explained so far. Soya bean meal given as a supplement along with small amounts of Acacia cyanophylla, tannin-rich shrub foliage, had beneficial effects in sheep fed on oat hay [23].

\section{Feed Mixtures}

Free-ranging animals can select their diets so as to avoid the worst effects of tannins. It is said that incidence of fatalities in which tannins have been implicated occur when animals are very hungry and are unable to select alternative feeds. In the cut and carry feeding systems of farmers, there are some indications that mixtures of different tree fodder are used on occasions, possibly in part as a strategy of avoiding possible toxicity due to excessive amounts of some fodder species. Lowry [90] observed that farmers usually minimize antinutritional problems by feeding leaf mixtures, which dilute or reduce toxic effects. Studies have shown that mixtures produced less deleterious effects than tanniniferous browses fed as sole feeds [44, 
$123,124,155,157,185]$. Using tree fodder as supplements to roughages may help in reducing the intake of tannins and may be the best strategy for herbivores to decrease the energy costs of detoxification [53], but the benefit that may be derived from such an approach for utilizing tannin-rich feeds has not been worked out.

\section{Addition of Energy Source}

A number of tannin-containing feeds have high levels of soluble sugars and/or starch and also a high nutritive value for both ruminants and non-ruminants. Some of these feeds are-fruits from Gleditsia triacanthos and Piliostigma thonningii, acorns from Quercus spp., P. cineraria and sainfoin leaves [138]. Although even low concentrations of carob tannins $(2.5 \mathrm{~g} \%)$ produced growth-depressing effects, the high concentrations of sugars $(4.7 \mathrm{~g} \%)$ in carob pulp may be responsible for the low but positive lamb growth rates of $48 \mathrm{~g} /$ day [163]. The addition of maize grain to browse leaves may have increased the weight gain of sheep either by balancing energy and protein requirements or by supplying energy for the detoxification process [219]. This hypothesis is also supported by observations that European roe deer (Capreolus capreolus) selected diets containing high concentrations of low molecular weight phenolics, tannins and soluble sugars [207]. A good source of energy is likely to assist in the detoxification of some tannins, low molecular weight phenolics or their metabolites. This could also explain why sugar-rich cactus (Opuntia ficus-indica) fruits, cactus pads and molasses removed the toxic effects of kermes oak (Q. coccifera) and increased the nutritive value of several browses [4, 19, 21, 176].

\section{Silages}

Silages prepared from tanniniferous plants tend to have reduced soluble nitrogen content, which improves their feeding value [3, 174, 181]. Only a few studies done so far have investigated the merits of conserving tannin-rich fodder in tropical countries for feeding during dry season. In one study, mixtures of grasses and tree leaves from Leucaena leucocephala or Gliricidia sepium were ensiled, resulting in high-quality silages which promoted weight gain in sheep, and apparently, a significant proportion of the "ruminal escape protein" survived the silage fermentation process [152]. It was observed that silages containing maize ( $\mathrm{Zea}$ mays) stover mixed with tree leaves from species of Calliandra, Acacia, Gliricidia or Leucaena could be used to replace commercial feed supplements for dry season and lactation feeding without loss of milk yield from dairy cows [206]. When L. corniculatus silage was fed to dairy cows, it compared favourably with alfalfa (Medicago sativa) and red clover (Trifolium pratense) silages. The dry matter intakes were similar among these silage diets, but milk and protein yields were higher for the $L$. corniculatus silage [69]. L. corniculatus silage also achieved a significantly higher nitrogen balance in lambs than red clover or alfalfa silage [55]. Goats fed with silage made from green tea (Camellia sinensis) waste and whole-crop oat (Avena sativa) had increased nitrogen retention [80]. The feed proteins possibly survived the ensiling process and were digested post-ruminally, as the added nitrogen did not increase ruminal ammonia, urinary or faecal nitrogen [81].

\section{Concluding Remarks}

There is a need for more in vivo experimental and pilot-scale studies at farm level for complete validation of these methods. Tannins by virtue of their structure-activity relationship and content in a plant biomass can act as a double-edged sword, and as such present a conundrum that requires a tannin content-specific solution [138]. Although tanniniferous feed and forages containing low to moderate level $(<5 \%$ dry matter) can be safely fed to animals with the added advantage of some beneficial effects to the animal, it is the high-tannin ( $>5 \%$ dry matter)-containing plant biomass which is the focus of attention. At 5-10\% tannin content, the approaches other than physical, chemical and biological methods can be tried. It is only at a tannin level of $>10 \%$ of the dry matter that one should think of physical and chemical methods as high-tannin content can only be inactivated or removed by these methods. The biological methods have not shown much success and need further refinement.

The aim of future studies would be to explore the potential of these approaches for a wide range of tanniniferous feed and fodder and then to develop simple and economically viable detanninification technologies for use by farmers for available feed and fodder resources. The feeding strategies, although lesser known but promising due to ease of use and cost-effectiveness, are supplementation, feed mixtures, addition of energy source and ensilage. Some of these techniques will have to be adapted and upgraded for use by small-scale industry to treat agroindustrial and forestry by-products which are available in large quantities at one place. These technologies will help in the value addition and utilization of various tanniniferous feed, fodder and agro-industrial byproducts and solve the problem of shortage of conventional feed and fodder in the developing countries. 
Conflict of interest None

\section{References}

1. Ahn JH, Robertson BM, Elliott R, Gutteridge RC, Ford CW (1989) Quality assessment of tropical browse legumes: tannin content and protein degradation. Anim Feed Sci Technol 27:147-156

2. Alam MR, Kabir AKMA, Amin MR, McNeill DM (2005) The effect of calcium hydroxide treatment on the nutritive and feeding value of Albizia procera for growing goats. Anim Feed Sci Technol 122:135-148

3. Albrecht RJ, Muck RE (1991) Proteolysis in ensiled forage legumes that vary in tannin concentration. Crop Sci 31:464-469

4. Aregheore EM, Perera D (2004) Effects of Erythrina variegata, Gliricidia sepium and Leucaena leucocephala on dry matter intake and nutrient digestibility of maize stover, before and after spraying with molasses. Anim Feed Sci Technol 111:191-201

5. Armstrong WD, Featherston WR, Rogler JC (1973) Influence of methionine and other dietary additions on the performance of chicks fed bird resistant, sorghum grain diets. Poult Sci 52: 1592-1599

6. Asquith TN, Butler GL (1986) Interactions of condensed tannins with selected proteins. Phytochemistry 25:1591-1593

7. Austin PJ, Suchar LA, Robbins CT, Hagerman AE (1989) Tannin-binding proteins in saliva of deer and their absence in saliva of sheep and cattle. J Chem Ecol 15:1335-1347

8. Awika JM, Rooney LW (2004) Sorghum phytochemicals and their potential impact on human health. Phytochemistry 65:1199-1221

9. Ayers AC, Barrett RP, Cheeke PR (1996) Feeding value of tree leaves (hybrid poplar and black locust) evaluated with sheep, goats, and rabbits. Anim Feed Sci Technol 57:51-62

10. Bae HD, McAllister TA, Yanke LJ, Cheng K-J, Muir AD (1993) Effects of condensed tannins on endoglucanase activity and filter paper digestion by Fibrobacter succinogenes S85. Appl Environ Microbiol 59:2132-2138

11. Banner RE, Rogosic J, Burritt EA, Provenza FD (2000) Supplemental barley and activated charcoal increase intake of sagebrush by lambs. J Range Manage 53:415-420

12. Barahona R, Lascano CE, Cochran RC, Morrill JL, Totgemeyer EC (1997) Proc XVIII International Grassland Congress Canada Paper ID No. 1206

13. Barahona R, Lascano CE, Cochran R, Morrill J, Titge-meyer EC (1997) Intake, digestion, and nitrogen utilization by sheep fed tropical legumes with contrasting tannin concen-tration and astringency. J Anim Sci 75:1633-1640

14. Barry TN, McNabb WC (1999) The implications of condensed tannins on the nutritive value of temperate forages fed to ruminants. Br J Nutr 81:263-272

15. Barry TN (1985) The role of condensed tannins in the nutritional value of Lotus pedunculatus for sheep. 3. Rates of body and wool growth. Br J Nutr 54:211-217

16. Barry TN, McNeill DM, McNabb WC (2001) Plant secondary compounds; their impact on forage nutritive value and upon animal production. In: Filho AMC (ed) Proc XIX International Grassland Congress. Brazilian Society of Animal Husbandry, Sao Paulo, pp 445-452

17. Barry TN, Duncan SJ (1984) The role of condensed tannins in the nutritional value of Lotus pedunculatus for sheep. 1. Voluntary intake. Br J Nutr 51:485-491

18. Begovic S, Duzic E, Sakirbegovic A, Tafro A (1978) Examination of tannase activity in ruminal contents and mucosa of goat fed oak leaves and during intraruminal application of 3 to $10 \%$ tannic acid. Veterinaria 4:445-457
19. Ben Salem H, Atti N, Priolo A, Nefzaoui A (2002) Polyethylene glycol in concentrate or feedblocks to deactivate condensed tannins in Acacia cyanophylla Lindl. foliage. 1. Effects on intake, digestion and growth by Barbarine lambs. Anim Sci 75:127-135

20. Ben Salem H, Nefzaoui A, Ben Salem L, Tisserand JL (1999) Different means of administering polyethylene glycol to sheep: effect on the nutritive value of Acacia cyanophylla Lindl. foliage. Anim Sci 68:809-818

21. Ben Salem H, Ben Salem L, Nefzaoui A, Ben Said MS (2003) Effect of PEG and olive cake feed blocks supply on feed intake, digestion, and health of goats given kermes oak (Quercus coccifera $\mathrm{L}$.) foliage. Anim Feed Sci Tech 110:45-59

22. Ben Salem H, Saghrouni L, Nefzaoui A (2005) Attempts to deactivate tannins in fodder shrubs with physical and chemical treatments. Anim Feed Sci Technol 122:109-121

23. Ben Salem H, Makkar HPS, Nefzaoui A, Hassayoun L, Abidi S (2005) Benefit from the association of small amounts of tanninrich shrub foliage (Acacia cyanophylla Lindl.) with soya bean meal given as supplements to Barbarine sheep fed on oaten hay. Anim Feed Sci Technol 122:173-186

24. Ben Salem H, Nefzaoui A, Makkar HPS (2007) Feed supplementation blocks for increased utilization of tanniniferous foliages by ruminants. In: FAO Technical paper 164, Feed supplementation blocks with Urea-molasses multinutrient blocks: simple and effective feed supplement technology for ruminant agriculture. FAO, Rome, pp 185-205

25. Ben-Ghedalia D, Tagari H (1977) Digestive and ruminal metabolism of sheep fed sorghum (S. vulgare) and maize $(Z$. mays) silages. Nutr Rep Int 6:657-660

26. Bhat TK, Makkar HPS, Singh B (1996) Isolation of a tanninprotein complex degrading fungus from faeces of hill cattle. Lett Appl Microbiol 22:257-258

27. Bhat TK, Makkar HPS, Singh B (1997) Preliminary studies on tannin degradation by Aspergillus niger van Tieghem MTCC 2425. Lett Appl Microbiol 25:22-23

28. Bhat TK, Singh B, Sharma OP (1998) Microbial degradation of tannins - a current perspective. Biodegradation 9:343-358

29. Bhatta R, Krishnamoorthy U, Mohammed F (2000) Effect of feeding tamarind (Tamarindus indica) seed husk as a source of tannin on dry matter intake, digestibility of nutrients and production performance of crossbred dairy cows in mid-lactation. Anim Feed Sci Technol 83:67-74

30. Bhatta R, Shinde AK, Vaithiyanathan S, Sankhyan SK, Verma DL (2002) Effect of polyethylene glycol-6000 on nutrient intake, digestion and growth of kids browsing Prosopis cineraria. Anim Feed Sci Technol 101:45-54

31. Bruno-Soares AM, Abreu JM (2003) Merit of Gleditsia triacanthos pods in animal feeding. Chemical composition and nutritional evaluation. Anim Feed Sci Technol 107:151-160

32. Butler LG (1992) Antinutritional effects of condensed and hydrolysable tannins. In: Hemingway RW, Laks PE (eds) Plant polyphenols. Plenum, New York, pp 693-698

33. Butler LG, Rogler JC (1992) Biochemical mechanisms of the antinutritional effects of tannins. In: Ho C, Lee CY, Huang M (eds) Phenolic compounds in food and their effects on health. I. Analysis, occurrence, and chemistry. ACS Symposium Series 506. American Chemical Society, Washington, pp 298-303

34. Cantos E, Espin JC, Lopez-Bote C, de la Hoz L, Ordonez JA, Tomas-Barberan FA (2003) Phenolic compounds and fatty acids from acorns (Quercus spp.), the main dietary constituent of freeranged Iberian pigs. J Agric Food Chem 51:6248-6255

35. Chang SI, Fuller HL (1964) Effect of tannin content of grain sorghum on their feeding value for growing chicks. Poult Sci 43:30-36 
36. Chaudhary LC, Agarwal N, Verma V, Rikhari K, Kamra DN (2011) Effect of feeding tannin degrading bacteria (Isolate-6) on rumen fermentation, nutrient utilization and growth performance of goats fed on Ficus infectoria leaves. Small Rumin Res 99: $143-147$

37. Cooney DO (1995) Activated charcoal in medical application. Marcel Dekker, New York

38. Coppock DL, Reed JD (1992) Cultivated and native browse legumes as calf supplements in Ethiopia. J Range Manage 45: 231-238

39. Dawson JM, Buttery PJ, Jenkins D, Wood CD, Gill M (1999) Effects of dietary quebracho tannin on nutrient utilisation and tissue metabolism in sheep and rats. J Sci Food Agric 79: 1423-1430

40. Decandia M, Sitzia M, Cabiddu A, Kababya D, Molle G (2000) The use of polyethylene glycol to reduce the anti-nutritional effects of tannins in goats fed woody species. Small Rumin Res 38:157-164

41. Deshpande SS, Cheryan M, Salunkhe DK (1986) Tannin analysis of food products. CRC Crit Rev Food Sci 24:401-449

42. Devendra C (1995) Composition and nutritive value of browse legumes. In: Devendra C, D'Mello JPF (eds) Tropical legumes in animal nutrition. $\mathrm{CAB}$ International UK, Wallingford, pp 49-65

43. Doce RR, Belenguer A, Toral PG, Hervás G, Frutos P (2011) Effect of the administration of young leaves of Quercus pyrenaica on rumen fermentation in relation to oak tannin toxicosis in cattle. J Anim Physiol Anim Nutr 94:227-236

44. Dube JS, Ndlovu LR (1995) Feed intake, chemical composition of faeces and nitrogen retention in goats consuming single browse species or browse mixtures. Zim J Agri Res 33:133-141

45. Dube JS, Reed JD, Ndlovu LR (2001) Proanthocyanidins and other phenolics in Acacia leaves of Southern Africa. Anim Feed Sci Technol 91:59-67

46. Dueñas M, Hernández T, Estrella I (2006) Changes in the content of bioactive polyphenolic compounds of lentils by the action of exogenous enzymes. Effect on their antioxidant activity. Food Chem 101:90-97

47. Dueñas M, Hernández T, Estrella I (2007) Influence of the action of exogenous enzymes on the polyphenolic composition of pea: effect on the antioxidant activity. Eur Food Res Technol 225:493-500

48. Dueñas M, Hernández T, Estrella I (2009) Comparative study of the phenolic composition in lentils processed with and without addition of commercial tannase. J Food Process Pres 33: 695-713

49. Fahey GC Jr, Jung H-JG (1989) Phenolic compounds in forages and fibrous feedstuffs. In: Cheeke PR (ed) Toxicants of plant origin, vol IV. CRC Press, Boca Raton, pp 123-130

50. FAO (1992) Legume trees and other fodder trees as protein sources for livestock. FAO Animal Production and Health paper No 102

51. Filippich LJ, Zhu J, Oelrichs P, Alsalami MT, Doig AJ, Cao GR, English PB (1991) Hepatotoxic and nephrotoxic principles in Terminalia oblongata. Res Vet Sci 50:170-177

52. Firenzuoli AM, Vanni P, Mastronuzzi E (1969) The effect of some aromatic compounds on pure enzymes and their subsequent reactivation by PVP and Tween 80 . Phytochemistry 8:61-64

53. Foley WJ, Iason GR, McArthur C (1999) Role of plant secondary metabolites in the nutritional ecology of mammalian herbivores: how far have we come in 25 years? In: Jung GH-J, Fahey GC (eds) Nutritional ecology of herbivores. American Society of Animal Science, Savoy, pp 130-209

54. Fowler ME, Richards WPC (1965) Acorn poisoning in a cow and a sheep. J Am Vet Med Assoc 147:1215-1220
55. Fraser MD, Fychan R, Jones R (2000) Voluntary intake, digestibility and nitrogen utilization by sheep fed ensiled forage legumes. Grass Forage Sci 55:271-279

56. Frutos P, Raso M, Hervas G, Mantecon AR, Perez V, Giraldez FJ (2004) Is there any detrimental effect when a chestnut hydrolysable tannin extract is included in the diet of finishing lambs? Anim Res 53:127-136

57. Gamble GR, Akin DE, Makkar HPS, Becker K (1996) Biological degradation of tannins in Sericea lespedeza by the white-rot fungi Ceriporiopsis subvermispora and Cyathus stercoreus analyzed by solid state ${ }^{13} \mathrm{C}$ NMR spectroscopy. Appl Environ Microbiol 62:3600-3604

58. Garg SK, Makkar HPS, Nagal KB, Sharma SK, Wadhwa DR, Singh B (1992) Toxicological investigations into oak (Quercus incana) leaf poisoning in cattle. Vet Hum Toxicol 34:161-164

59. Getachew G, Makkar HPS, Becker K (2001) Method of polyethylene glycol application to tannin-containing browses to improve microbial fermentation and efficiency of microbial protein synthesis from tannin-containing browses. Anim Feed Sci Technol 92:51-57

60. Graham HN (1992) Green tea composition, consumption and polyphenol chemistry. Prev Med 21:334-350

61. Gutteridge RC, Shelton HM (1994) The role of forage tree legumes in cropping and grazing systems. In: Gutteridge RC, Shelton HM (eds) Forage tree legumes in tropical agriculture. CAB International UK, Wallingford, pp 3-11

62. Haddock EA, Gupta RK, Al-Shafi SMK, Lyden K, Haslam E, Magnolato D (1982) The metabolism of gallic acid and hexahydroxydiphenic acid in plants. Biogenic and molecular taxonomic considerations. Phytochemistry 21:1049-1062

63. Hagerman AE, Robbins CT, Weerasuriya Y, Wilson TC, McArthur C (1992) Tannin chemistry in relation to digestion. J Range Manage 45:57-62

64. Hervas G, Frutos P, Giraldez FJ, Mantecon AR, del Pino MCA (2003) Effect of different doses of quebracho tannins extract on rumen fermentation in ewes. Anim Feed Sci Technol 109:65-78

65. Hill R (1991) Rapeseed meal in the diets of ruminants. Nutr Abst Rev (Series B) 61:139-155

66. Holechek JL, Munshikpu AV, Saiwana L, Nunez-Hernandez G, Valdez R, Wallace JD, Cardenas M (1990) Influences of six shrub diets varying in phenol content on nitrogen retention by goats. Trop Grasslands 24:93-98

67. Horigome T, Ohkuma T, Muta M (1984) Effect of condensed tannins of false acacia leaves on protein digestibility as measured with rats. Jpn J Zootech Sci 55:299-306

68. Hove L, Topps JH, Sibanda S, Ndlovu LR (2001) Nutrient intake and utilization by goats fed dried leaves of the shrub legumes Acacia angustissima, Calliandra calothyrsus and Leucaena leucocephala as supplements to native pasture hay. Anim Feed Sci Technol 91:95-106

69. Hymes-Fecht UC, Broderick GA, Muck RE, Grabber JD (2004) Effects of feeding legume silage with differing tannin levels on lactating dairy cattle. J Dairy Sci 87(Suppl 1):249-256

70. Ishihara N, Chu DC, Akachi S, Juneja LR (2001) Improvement of intestinal microflora balance and prevention of digestive and respiratory organ diseases in calves by green tea extracts. Livestock Prod Sci 68:217-229

71. Jones GA, McAllister TA, Muir AD, Cheng K-J (1994) Effects of sainfoin (Onobrychis viciifolia Scop.) condensed tannins on growth and proteolysis by four strains of ruminal bacteria. Appl Environ Microbiol 60:1374-1378

72. Jones RJ, Galgal KK, Castillo AC, Palmer B, Deocareza A, Bolam M (1998) Animal production from five species of $\mathrm{Leu}$ caena. ACIAR Proc 86:247-252

73. Jones WT, Mangan JL (1977) Complexes of the condensed tannins of sainfoin (Onobrychis viciifolia Scop.) with fraction 1 
leaf protein and with submaxillary mucoprotein, and their reversal by polyethylene glycol and $\mathrm{pH}$. J Sci Food Agric 28:126-136

74. Joslyn MA, Nishira H, Ito S (1968) Leucoanthocyanins and related phenolic compounds of carob pods (Ceratonia siliqua). J Sci Food Agr 19:543-550

75. Kahiya C, Mukaratirwa S, Thamsborg SM (2003) Effects of Acacia nilotica and Acacia karoo diets on Haemonchus contortus infection in goats. Vet Parasitol 115:265-274

76. Khanal RC, Subba DB (2001) Nutritional evaluation of leaves from some major fodder trees cultivated in the hills of Nepal. Anim Feed Sci Tech 92:17-32

77. Kiangi EMI, Kategile JA (1981) Different sources of ammonia for improving the nutritive value of low quality roughages. Anim Feed Sci Technol 6:377-386

78. Kingsbury JM (1964) Poisonous plants of the United States and Canada. Prentice-Hall Inc, Englewood Cliffs, pp 626-635

79. King RH, Eason PE, Kerton DK, Dunshea FR (2001) Evaluation of solvent-extracted canola meal for growing pigs and lactating sows. Aust J Agric Res 52:1033-1041

80. Kondo M, Kita K, Yokota H (2004) Feeding value to goats of whole-crop oat ensiled with green tea waste. Anim Feed Sci Technol 113:71-81

81. Kondo M, Kita K, Yokota H (2005) Erratum to 'Feeding value to goats of whole-crop oat ensiled with green tea waste'. Anim Feed Sci Technol 119:187-188

82. Krebs GL, Howard DM, Dods K (2007) The effects of feeding Acacia saligna on feed intake, nitrogen balance and rumen metabolism in sheep. Asian Aust J Anim Sci 20:1367-1373

83. Krisper P, Tisler V, Skubic V, Rupnik I, Kobal S (1992) The use of tannin from chestnut (Castanea vesca). In: Hemingway RW, Laks PE (eds) Plant polyphenols. Plenum, New York, pp 1013-1019

84. Kumar R, D’Mello JPF (1995) Anti-nutritional factors in forage legumes. In: D'Mello JPF, Devendra C (eds) Tropical legumes in animal nutrition. CAB International UK, Wallingford, pp 95-133

85. Kumar R, Horigome T (1986) Fractionation, characterization and protein precipitating capacity of the condensed tannins from Robinia pseudoacacia (L.) leaves. J Agric Food Chem 34: 487-489

86. Kumar R, Vaithiyanathan S (1990) Occurrence, nutritional significance and effect on animal productivity of tannins in tree leaves. Anim Feed Sci Technol 30:21-38

87. Kyarissiima CC, Okot MW, Svihus S (2004) Use of wood ash in the treatment of high tannin sorghum for poultry feeding. S Afr J Anim Sci 34:110-115

88. Lohan OP, Lall D, Vaid J, Negi SS (1983) Utilization of oak tree (Quercus incana) fodder in cattle rations and fate of oak-leaf tannins in the ruminant systems. Indian J Anim Sci 53:1057-1063

89. Lorusso L, Lacki K, Duvnjak Z (1996) Decrease of tannin content in canola meal by an enzyme preparation from Trametes versicolor. Biotechnol Lett 18:309-314

90. Lowry JB (1990) Toxic factors, problems and methods of alleviating these in farm animals. In: Devendra C (ed) Shrubs and tree fodders for farm animals. Ottawa, IDRC, pp 76-88

91. Lowry JB, McSweeney CS, Palmer B (1996) Changing perceptions of the effect of plant phenolics on nutrient supply in the ruminant. Aust J Agr Res 47:829-842

92. Lyford SJ, Smart WWG Jr, Bell TA (1967) Inhibition of cellulose digestion by extracts of Sericea lespedeza. J Anim Sci 26:632-637

93. Makkar HPS (1993) Antinutritional factors in foods for livestock. In: Gill M, Owen E, Pollott GE, Lawrence TLJ (ed) Animal production in developing countries, Occasional Publication No 16, Midlothian, Scotland, British Society of Animal Production, pp 69-85
94. Makkar HPS, Becker K (1994) Isolation of tannins from trees and shrubs and their properties. J Agric Food Chem 42:731-734

95. Makkar HPS, Becker K (1996) Effect of pH, temperature, and time on inactivation of tannins and possible implications in detannification studies. J Agric Food Chem 44:1291-1295

96. Makkar HPS, Singh B (1991) Effect of drying conditions on tannin, fibre and lignin levels in mature oak (Quercus incana) leaves. J Sci Food Agric 54:323-328

97. Makkar HPS, Singh B (1992) Effect of wood ash on tannin content of oak (Quercus incana) leaves. Bioresour Technol 41: $85-86$

98. Makkar HPS, Singh B (1992) Effect of steaming and autoclaving oak (Quercus incana) leaves on levels of tannins, fibre and lignin and in sacco dry matter digestibility. J Sci Food Agric 59:469-472

99. Makkar HPS, Singh B (1992) Detannification of oak leaves: treatments and their optimization. Anim Feed Sci Tech 36: $113-127$

100. Makkar HPS (2003) Effects and fate of tannins in ruminant animals, adaptation to tannins, and strategies to overcome detrimental effects of feeding tannin-rich feeds. Small Rumin Res 49:241-256

101. Makkar HPS, Singh B, Dawra RK (1988) Effect of tannin-rich leaves of oak on various microbial activities of the rumen. $\mathrm{Br} \mathbf{J}$ Nutr 60:287-296

102. Makkar HPS, Singh B, Kamra DN (1994) Biodegradation of tannin in oak (Quercus incana) leaves by Sporotricum pulverulentum. Lett Appl Microbiol 18:42-44

103. Makkar HPS, Singh B, Negi SS (1989) Relationship of rumen degradability with biomass accumulation, cell wall constituents and tannin levels in some tree leaves. Anim Prod 49:299-303

104. Makkar HPS, Singh B (1993) Effect of storage and urea addition on detannification and in sacco dry matter digestibility of mature oak (Quercus incana) leaves. Anim Feed Sci Tech 41:247-259

105. Mlambo V, Smith T, Owen E, Mould FL, Sikosana JLN, Mueller-Harvey I (2004) Tanniniferous Dichrostachys cinerea fruits do not require detoxification for goat nutrition: in sacco and in vivo evaluations. Livestock Prod Sci 90:135-144

106. Manach C, Scalbert A, Morand C, Rémésy C, Jimenez L (2004) Polyphenols: food sources and bioavailability. Am J Clin Nutr 79:727-747

107. Mangan JL (1988) Nutritional effects of tannins in animal feeds. Nutr Res Rev 1:209-231

108. Marais JPJ, Mueller-Harvey I, Brandt EV, Ferreira D (2000) Polyphenols, condensed tannins, and other natural products in Onobrychis viciifolia (sainfoin). J Agric Food Chem 48:3440-3447

109. Marquardt RR, Ward T (1979) Chick performance as affected by autoclave treatment of tannin-containing and tannin-free cultivars of faba beans. Can J Anim Sci 59:781-782

110. Marquardt RR, Ward AT, Campbell LD, Cansfield PE (1977) Purification, identification and characterization of a growth inhibitor in faba beans (Vicia faba L. minor) and its depressive effect on the appetite and nutrient availability in the chick. J Nutr 107:1313-1324

111. Martin SA, Akin DE (1988) Effects of phenolic monomers on the growth and b-glucosidase activity of Bacteroides ruminicola and on the carboxymethylcellulase, $\mathrm{b}$-glucosidase, and xylanase activities of Bacteroides succinogenes. Appl Environ Microb 54:3019-3022

112. McArthur C, Hagerman A, Robbins CT (1991) Physiological strategies of mammalian herbivores against plant defenses. In: Palo RT, Robbins CT (ed) Plant defenses against mammalian herbivory. CRC Press, Boca Raton, pp 103-114

113. McArthur C, Sanson GD, Beal AM (1995) Salivary proline-rich proteins in mammals: roles in oral homeostasis and counteracting dietary tannin. J Chem Ecol 21:663-691 
114. McCabe SM, Barry TN (1988) Nutritive value of willow (Salix sp.) for sheep, goats and deer. J Agric Sci (Camb) 111:1-9

115. McDonald P, Edwards RA, Greenhalgh IFD (1995) Animal nutrition, 5th edn. Longman Scientific and Technical, England, pp 477-479

116. McLeod MN (1974) Plant tannins- their role in forage quality. Nutr Abst Rev 44:803-815

117. McMahon LR, McAllister TA, Berg BP, Majak W, Acharya SN, Popp JD, Coulman BE, Wang Y, Cheng K-J (2000) A review of the effects of forage condensed tannins on ruminal fermentation and bloat in grazing cattle. Can J Plant Sci 80:469-485

118. McNeill DM, Osborne NJ, Komolong M, Nankervis D (1998) Condensed tannins in the genus Leucaena and their nutri-tional significance for ruminants. ACIAR Proc 86:205-214

119. McSweeney CS, Kennedy PM, John A (1988) Effect of ingestion of hydrolysable tannins in Terminalia oblongata on digestion in sheep fed Stylosanthes hamata. Aust J Agric Res 39:235-244

120. McSweeney CS, Palmer B, McNeill DM, Krause DO (2001) Microbial interactions with tannins: nutritional consequences for ruminants. Anim Feed Sci Tech 91:83-93

121. McWilliam EL, Barry TN, Lopez-Villalobos N, Cameron PN, Kemp PD (2005) Effects of willow (Salix) supplementation for 31 and $63 \mathrm{~d}$ on the reproductive performance of ewes grazing low quality drought pasture during mating. Anim Feed Sci Technol 119:87-106

122. Meagher LP, Lane G, Sivakumaran S, Tavendale MH, Fraser K (2004) Characterization of condensed tannins from Lotus species by thiolytic degradation and electrospray mass spectrometry. Anim Feed Sci Technol 117:151-163

123. Melaku S, Peters KJ, Tegegne A (2004) Microbial nitrogen supply, nitrogen retention and rumen function in Menz sheep supplemented with dried leaves of multipurpose trees, their mixtures or wheat bran. Small Rumin Res 52:25-36

124. Melaku S, Peters KJ, Tegegne A (2005) Intake, digestibility and passage rate in Menz sheep fed tef (Eragrostis tef) straw supplemented with dried leaves of selected multipurpose trees, their mixtures or wheat bran. Small Rumin Res 56:139-149

125. Miller SM, Brooker JD, Phillips A, Blackall LL (1995) A feral goat rumen fluid inoculum improves nitrogen retention in sheep consuming a mulga (Acacia aneura) diet. Aust J Agr Res 46:1545-1553

126. Miller SM, Brooker JD, Phillips A, Blackall LL (1996) Streptococcus caprinus is ineffective as a rumen inoculum to improve digestion of mulga (Acacia aneura) by sheep. Aust J Agric Res 47:1323-1331

127. Miller SM, Klieve AV, Plumb JJ, Aisthorpe R, Blackall LL (1997) An in vitro cultured rumen inoculum improves nitrogen digestion in mulga-fed sheep. Aust J Agric Res 48:403-409

128. Mlambo V, Smith T, Owen E, Mould FL, Sikosana JLN, Mueller-Harvey I (2004) Tanniniferous Dichrostachys cinerea fruits do not require detoxification for goat nutrition: in sacco and in vivo evaluations. Livestock Prod Sci 90:135-144

129. Mole S, Waterman PG (1985) Stimulatory effects of tannins and cholic acid on tryptic hydrolysis of proteins: ecological implications. J Chem Ecol 11:1323-1332

130. Molina DO, Pell AN, Hogue DE (1999) Effects of ruminal inoculations with tannin-tolerant bacteria on fibre and nitrogen digestibility of lambs fed a high condensed tannin diet. Anim Feed Sci Technol 81:69-80

131. Moore KM, Barry TN, Cameron PN, Lopez-Villalobos N, Cameron DJ (2003) Willow (Salix sp.) as a supplement for grazing cattle under drought conditions. Anim Feed Sci Technol 104:1-11

132. Mturi FA (1991) The feeding ecology and behaviour of the Red Colobus monkey. (Ph D dissertation). University of Dar es Salaam, Tanzania
133. Mturi FA (1993) Ecology of the Zanzibar Red Colobus monkey, Colobus badius kirkii (Gray, 1968), in comparision with other red colobines. In: Lovett JC, Wasser SK (eds) Biogeography and ecology of the rain forest of eastern Africa. Cambridge University Press, Cambridge

134. Mueller-Harvey I, Reed JD, Hartley RD (1987) Characterization of phenolic compounds, including flavonoids and tannins, of 10 Ethiopian browse species by high performance liquid chromatography. J Sci Food Agric 39:1-14

135. Mueller-Harvey I, Reed JD (1992) Identification of phenolic compounds and their relationships to in vitro digestibility of sorghum leaves from bird-resistant and non-bird-resistant varieties. J Sci Food Agric 60:179-196

136. Mueller-Harvey I (1999) Tannins: their nature and biological significance. In: Caygill JC, Mueller-Harvey I (eds) Secondary plants products. Antinutritional and beneficial actions in animal feeding. Nottingham University Press, UK, pp 17-70

137. Mueller-Harvey I, McAllan AB (1992) Tannins: their biochemistry and nutritional properties. In: Morrison IM (ed) Advances in plant cell biochemistry and biotechnology, vol 1. JAI Press Ltd, London, pp 151-217

138. Mueller-Harvey I (2006) Unravelling the conundrum of tannins in animal nutrition and health. J Sci Food Agric 86:2010-2037

139. Mueller-Harvey I, McAllan AB, Theodorou MK, Beever DE (1988) Phenolics in fibrous crop residues and plants and their effects on digestion and utilization of carbohydrates and proteins in ruminants. In: Reed JD, Capper BS, Neate PJH (ed) Plant breeding and the nutritive value of crop residues ( $p$ 97). Proceedings of a workshop held at ILCA, Addis Ababa, Ethiopia

140. Mueller-Harvey I, Reed JD, Reed JD, Hartley RD (1987) Characterization of phenolic compounds, including tannins of ten Ethiopian browse species by high performance liquid chromatography. J Sci Food Agr 39:1-14

141. Muir JP (2011) The multi-faceted role of condensed tannins in the goat ecosystem. Small Rumin Res 98:115-120

142. Mukuru SZ, Butler LG, Rogler JC, Kirleis AW, Ejeta G, Axtell JD, Mertz ET (1992) Traditional processing of high-tannin sorghum grain in Uganda and its effect on tannin, protein digestibility, and rat growth. J Agric Food Chem 40:1172-1175

143. Murdiati TB, McSweeney CS, Campbell RSF, Stoltz DS (1990) Prevention of hydrolysable tannin toxicity in goats fed Clidemia hirta by calcium hydroxide supplementation. J Appl Toxicol 10:325-331

144. Murdiati TB, McSweeney CS, Lowry JB (1992) Metabolism in sheep of gallic acid, tannic acid and hydrolyzable tannin from Terminalia oblongata. Aust J Agric Res 43:1307-1319

145. Nastis AS, Malechek JC (1981) Digestion and utilization of nutrients in oak browse by goats. J Anim Sci 53:283-290

146. Ncube S, Mubaiwa E (1993) The use of Browse Plus in improving the feeding value of Acacia fruits. J Zim Soc Anim Prod 6:77-80

147. Negi SS, Pal RN, Ehrich C (1979) Tree Fodders in Himachal Pradesh (India): An introduction to the six most common fodder trees in the Himachal Pradesh State of India and their feeding value for cattle. German Agency for Technical Cooperation, Eschborn, pp 1-66

148. Negi SS (1982) Tannins in sal seed (Shorea robusta) and sal seed meal limit their utilization as livestock feeds. Anim Feed Sci Technol 7:161-183

149. Neser JA, Coetzer JAW, Boomker J, Cable H (1982) Oak (Quercus rubor) poisoning in cattle. J S Afr Vet Assoc 38:151-155

150. Niezen JH, Robertson HA, Waghorn GC, Charleston WAG (1998) Production, faecal egg counts and worm burdens of ewe lambs which grazed six contrasting forages. Vet Parasitol 80:15-27

151. Norton BW, Ahn JHA (1997) Comparison of fresh and dried Calliandra calothyrsus supplements for sheep given a basal diet of barley straw. J Agric Sci (Camb) 129:485-494 
152. Norton BW (1994) Tree legumes as dietary supplements for ruminants. In: Gutteridge RC, Shelton HM (eds) Forage tree legumes in tropical agriculture. $\mathrm{CAB}$ International $\mathrm{UK}$, Wallingford, pp 192-201

153. O'Donovan L, Brooker JD (2001) Effect of hydrolysable and condensed tannins on growth, morphology and metabolism of Streptococcus gallolyticus (S. caprinus) and Streptococcus bovis. Microbiology 147:1025-1033

154. Palmer B, McSweeney CS (2000) Tannins in Calliandra calothyrsus: effect of polyethylene glycol (PEG) and an evaluation of 19 accessions. In Brooker JD (ed) Tannins in livestock and human nutrition. Proceedings No. 92 Adelaide: ACIAR, pp 36-39

155. Pamo TE, Fonteh FA, Tendonkeng F, Kana JR, Boukila B, Djaga PJ, Fomewang G II (2006) Influence of supplementary feeding with multipurpose leguminous tree leaves on kid growth and milk production in the West African dwarf goat. Small Rumin Res 63:142-149

156. Panda SK, Panda NC, Sahu BK (1983) Effect of tree-leaf tannin on dry matter intake by goats. Indian Vet J 60:660-664

157. Patra AK, Sharma K, Dutta N, Pattanaik AK (2003) Response of gravid does to partial replacement of dietary protein by a leaf meal mixture of Leucaena leucocephala, Morus alba and Azadirachta indica. Anim Feed Sci Technol 109:171-182

158. Patra AK, Saxena J (2011) Exploitation of dietary tannins to improve rumen metabolism and ruminant nutrition. J Sci Food Agric 91:24-37

159. Pérez V, Doce RR, García-Pariente C, Hervás G, Carmen Ferreras M, Mantecón AR, Frutos P (2011) Oak leaf (Quercus pyrenaica) poisoning in cattle. Res Vet Sci 91:269-277

160. Plumlee KH, Johnson B, Galey FD (1998) Comparison of disease in calves dosed orally with oak or commercial tannic acid. J Vet Diagn Invest 10:263-267

161. Poage GWI, Scott CB, Bission MG, Hartman FS (2000) Activated charcoal attenuates bitter weed toxicosis in sheep. J Range Manage 53:73-78

162. Priolo A, Lanza M, Biondi L, Pappalardo P, Young OA (1998) Effect of partially replacing dietary barley with $20 \%$ carob pulp on post-weaning growth, and carcass and meat characteristics of Comisana lambs. Meat Sci 50:355-363

163. Priolo A, Waghorn GC, Lanza M, Biondi L, Pennisi P (2000) Polyethylene glycol as a means for reducing the impact of condensed tannins in carob pulp: effects on lamb growth performance and meat quality. J Anim Sci 78:810-816

164. Pritchard DA, Stocks DC, O'Sullivan BM, Martin PR, Hurwood IS, O'Rourke PK (1988) The effect of polyethylene glycol (PEG) on wool growth and liveweight of sheep consuming a mulga (Acacia aneura) diet. Proc Aus Soc Anim Sci 17:290-293

165. Provenza FD, Ortega-Reyes L, Scott CB, Lynch JJ, Burritt EA (1994) Antiemetic drugs attenuate food aversions in sheep. J Anim Sci 72:1989-1994

166. Pryor WJ, McDonald WJF, Seawright AA (1972) Supplejack (Ventilago viminalis) feeding of sheep, nutritional and toxicological investigations. Aust Vet J 48:339-344

167. Raharjo YC, Cheeke PR, Patton NM (1990) Effect of cecotrophy on the nutrient digestibility of alfalfa and black locust leaves. J Appl Rabbit Res 13:56-61

168. Rakesh DD, Bhat TK, Singh B (2000) Effect of fungal treatment on composition, tannin levels and digestibility of black locust (Robinia pseudoacacia) leaves. J Gen Appl Microbiol 46:99-103

169. Rayudu GVN, Kadirvel R, Vohra P, Kratzer FH (1970) Effect of various agents in alleviating the toxicity of tannic acid for chickens. Poult Sci 49:1323-1326

170. Reed JD, McDowell RE, Van Soest PJ, Horvath PJ (1982) Condensed tannins: a factor limiting the use of cassava forage. J Sci Food Agric 33:213-220
171. Reed JD (1995) Nutritional toxicology of tannins and related polyphenols in forage legumes. J Anim Sci 73:1516-1528

172. Reed JD, Soller H, Woodward A (1990) Fodder tree and straw diets for sheep: intake, growth, digestibility and the effects of phenolics on nitrogen utilization. Anim Feed Sci Technol 30:39-50

173. Reynolds L, Mureithi J, Mullins G, Thorpe W (1993) Food resource availability and milk production on smallholder dairy farms in the sub-humid coastal region of Kenya. In: Gill M, Owen E, Pollott GE, Lawrence TLJ (eds) Animal production in developing countries, Occasional Publication No 16. British Society of Animal Production, Midlothian, pp 158-159

174. Rioux R, Dossantos GT, Petit HV, Proulx JG (1995) Effect of cultivars on in vitro and ruminal degradation of the nitrogen fraction in birdsfoot trefoil silage. J Dairy Sci 78:1766-1773

175. Robbins CT, Hagerman AE, Austin PJ, McArthur C, Hanley TA (1991) Variation in mammalian physiological responses to a condensed tannin and its ecological implications. J Mammal 72:480-486

176. Robins C, Brooker JD (2005) The effects of Acacia aneura feeding on abomasal and intestinal structure and function in sheep. Anim Feed Sci Technol 121:205-215

177. Rochfort S, Parker AJ, Dunshea FR (2008) Plant bioactives for ruminant health and productivity. Phytochemistry 69:299-322

178. Russel RW, Lolley JR (1989) Deactivation of tannin in high tannin milo by treatment with urea. J Dairy Sci 72:2427-2430

179. Sahnoune S, Besle JM, Chenost M, Jouany JP, Combes D (1991) Treatment of straw with urea. 1. Ureolysis in a low water medium. Anim Feed Sci Technol 34:75-93

180. Salawu MB, Acamovic T, Stewart CS, Hovell FDD, McKay I (1997) Assessment of the nutritive value of Calliandra calothyrsus: in sacco degradation and in vitro gas production in the presence of Quebracho tannins with or without Browse Plus. Anim Feed Sci Technol 69:219-232

181. Salawu MB, Acamovic T, Stewart CS, Hvelplund T, Weisbjerg MR (1999) The use of tannins as silage additives: effects on silage composition and mobile bag disappearance of dry matter and protein. Anim Feed Sci Technol 82:243-259

182. Scalbert A (1991) Antimicrobial properties of tannins. Phytochemistry 30:3875-3883

183. Schons PF, Ries EF, Battestin V, Macedo GA (2011) Effect of enzymatic treatment on tannins and phytate in sorghum (Sorghum bicolor) and its nutritional study in rats. Int J Food Sci Technol 46:1253-1258

184. Sharma S, Bhat TK, Dawra RK (1999) Isolation, purification and properties of tannase from Aspergillus niger van Tieghem. World J Microbiol Biotech 15:673-677

185. Sharma R, Sahoo A, Singh B (2008) Exploring feeding value of oak (Quercus incana) leaves: nutrient intake and utilization in calves. Livestock Sci 118:157-165

186. Shi ZC (1988) Identification of the phenolic substances in bovine urine associated with oak leaf poisoning. Res Vet Sci 45:152-155

187. Sikosana JLN, Smith T, Mlambo V, Owen E, Mueller-Harvey I, Mould F (2002) Acacia and other tree fruits as dry season feed supplements for goats. In: Smith T, Godfrey SH, Buttery PJ, Owen E (eds) Helping small-stock keepers enhance their livelihoods: improving management of smallholder owned sheep and goats by utilizing local resources. Natural Resources International, Aylesford, pp 69-75

188. Silanikove N, Gilboa N, Nitsan Z (1997) Interactions among tannins, supplementation, and polyethylene glycol in goats fed oak leaves. Anim Sci 64:479-483

189. Silanikove N, Gilboa N, Perevolotsky A, Nitsan Z (1996) Goats fed tannin-containing leaves do not exhibit toxic syndromes. Small Rumin Res 21:195-201 
190. Silanikove N, Gilboa N, Nir I, Perevolotsky A, Nitsan Z (1996) Effect of a daily supplementation of polyethylene glycol on intake and digestion of tannin-containing leaves (Quercus calliprinos, Pistacia lentiscus and Ceratonia siliqua) by goats. J Agric Food Chem 44:199-205

191. Silanikove N, Nitsan Z, Perevolotsky A (1994) Effect of polyethylene glycol supplementation on intake and digestion of tannin-containing leaves (Ceratonia siliqua) by sheep. J Agric Food Chem 42:2844-2847

192. Sliwinski BJ, Kreuzer M, Sutter F, Machmuller A, Weststein HR (2004) Performance, body nitrogen conversion and nitro-gen emission from manure of dairy cows fed diets supplemented with different plant extracts. J Anim Feed Sci 13:73-91

193. Singh B, Negi SS (1986) Effect on wool production of supplementing black locust (Robinia pseudoacacia) and biul (Grewia optiva) leaves ad libitum to a concentrate diet for Angora rabbits. J Appl Rabbit Res 9:159-163

194. Singh B, Bhat TK (2001) Tannins revisited — changing perceptions of their effects on animal system. Anim Nutr Feed Technol 1:3-18

195. Singh B, Bhat TK (2003) Anti-nutritional factors in top feeds. In: Jakhmola RC, Jain RK (eds) Sustainable animal production. Pointer Publications, Jaipur, pp 225-263

196. Singh B, Sahoo A, Sharma R, Bhat TK (2005) Effect of polyethylene glycol on gas production parameters and nitrogen disappearance of some tree forages. Anim Feed Sci Technol 123-124:351-364

197. Singh B, Bhat TK, Sharma OP, Kanwar SS, Rahi P, Gulati A (2012) Isolation of tannase-producing Enterobacter ludwigii GRT-1 from the rumen of migratory goats. Small Rumin Res 102:172-176

198. Smart WWG Jr, Bell TA, Stanley NW, Cope WA (1961) Inhibition of rumen cellulose by an extract from sericea forage. J Dairy Sci 44:1945-1946

199. Smith T, Mlambo V, Sikosana JLN, Maphosa V, Mueller-Harvey I, Owen E (2005) Dichrostachys cinerea and Acacia nilotica fruits as dry season feed supplements for goats in a semi-arid environment-summary results from a DFID funded project in Zimbabwe. Anim Feed Sci Technol 122:149-157

200. Spier SJ, Smith BP, Seawright AA, Norman BB, Ostrowski SR, Oliver MN (1987) Oak toxicosis in cattle in Northern California: clinical and pathologic findings. J Am Vet Med Assoc 191:958-964

201. Stienezen M, Waghorn GC, Doughlas GB (1996) Digestibility and effects of condensed tannins on digestion of sulla ( $\mathrm{He}$ dysarum coronarium) when fed to sheep. $\mathrm{N}$ Z J Agric Res 39:215-221

202. Struhsaker TT, Cooney DO, Siex KS (1997) Adsorptive capacity of charcoals eaten by Zanzibar red colobus monkeys: its function and its ecological and demographic consequences. Int J Primatol 18:61-72

203. Tamir M, Alumot E (1970) Carob tannins-growth depression and levels of insoluble nitrogen in the digestive tract of rats. J Nutr 100:573-580

204. Terblance M, Pienaar JG, Bigalki R, Vahrmeyer J (1967) Acacia nilotica (L.) del subsp. Kraussiana (Benth.) Brenan as a poisonous plant in South Africa. J S Afr Vet Med Assoc 38:57-63

205. Thapa B, Walker DH, Sinclair FL (1997) Indigenous knowledge of the feeding value of tree fodder. Anim Feed Sci Technol 67:97-114

206. Titterton M (2001) Forage production and conservation for dry season feeding of dairy cattle in the semi-arid region of Zimbabwe. In: Smith T, Godfrey SH (ed) Sustaining livestock in challenging dry season environments: Strategies for smallscale livestock farmers. Proceedings 3rd livestock production programme projects. Chatham: Natural Resources International, pp 73-75
207. Tixier H, Duncan P, Scehovic J, Yani A, Gleizes M, Lila M (1997) Food selection by European roe deer (Capreolus capreolus): effects of plant chemistry, and consequences for the nutritional value of their diets. J Zool (London) 242:229-245

208. Urbano G, López-Jurado M, Porres JM, Frejnagel S, GómezVillalva E, Frías J, Vidal-Valverde C, Aranda P (2007) Effect of treatment with $\alpha$-galactosidase, tannase or a cell-wall-degrading enzyme complex on the nutritive utilisation of protein and carbohydrates from pea (Pisum sativum L.) flour. J Sci Food Agric 87:1356-1363

209. Vitti DMSS, Nozella EF, Abdalla AL, Bueno ICS, Silva Filho JC, Costa C, Bueno MS, Longo C, Vieira MEQ, Cabral Filho SLS, Godoy PB, Mueller-Harvey I (2005) The effect of drying and urea treatment on nutritional and anti-nutritional components of browses collected during wet and dry seasons. Anim Feed Sci Technol 122:123-133

210. Waghorn GC, Molan AL (2001) Effect of condensed tannins in Dorycnium rectum on its nutritive value and on the development of sheep parasite larvae. Proc N Z Grassland Assoc 63:273-277

211. Waghorn GC, Jones WT, Shelton ID, McNabb WC (1990) Condensed tannins and the nutritive value of herbage. Proc N Z Grassland Assoc 51:171-176

212. Walker DH, Thorne PJ, Sinclair FL, Thapa B, Wood CD, Subba DB (1999) A systems approach to comparing indigenous and scientific knowledge: consistency and discriminatory power of indigenous and laboratory assessment of the nutritive value of tree fodder. Agric Syst 62:87-103

213. Wang Y, Waghorn GC, Barry TN, Shelton ID (1994) The effect of condensed tannins in Lotus corniculatus on plasma metabolism of methionine, cystine and inorganic sulphate by sheep. $\mathrm{Br}$ J Nutr 72:923-935

214. Wang Y, Douglas GB, Waghorn GC, Barry TN, Foote AG, Purchas RW (1996) Effect of condensed tannins upon the performance of lambs grazing Lotus corniculatus and lucerne (Medicago sativa). J Agric Sci (Cambridge) 126:87-98

215. Wang Y, Douglas GB, Waghorn GC, Barry TN, Foote AG (1996) Effect of condensed tannins in Lotus corniculatus upon lactation performance in ewes. J Agric Sci (Camb) 126:353-362

216. Wareham CN, Wiseman J, Cole DJA, Draigon J (1991) The possible role of methionine in the detoxification of faba bean (Vicia faba L.) tannins in chick diets. Br Poult Sci 32:1017-1026

217. Waterman PG, Mole S (1994) Analysis of phenolic plant metabolites. In: Lawton JH, Likens GE (eds) Methods in ecology. Blackwell Scientific Publications, Oxford, p 248

218. West JW, Hill GM, Utley PR (1993) Peanut skins as a feed ingredient for lactating dairy cows. J Dairy Sci 76:590-599

219. Wiegand RO, Reed JD, Combs DK, Said AN (1996) Leaves from tropical trees as protein supplements in diets for sheep. Trop Agric 73:62-68

220. Wina E, Tangendjaja B, Susana IWR (2005) Effects of chopping, and soaking in water, hydrochloric acidic and calcium hydroxide solutions on the nutritional value of Acacia villosa for goats. Anim Feed Sci Technol 122:79-92

221. Wina E, Susana IWR, Tangendjaja B (2009) Detannification of Calliandra calothyrsus: the effect on digestibility and performance of rabbits. Livestock Res Rural Dev 21:1-11

222. Windham WR, Petersen JC, Terrill T (1990) Tannins as antiquality factors in forage. In: Akin DE, Ljungdahl LG, Wilson JR, Harris PJ (eds) Microbial and plant opportunities to improve lignocellulose utilizations by ruminants. Elsevier, New York, pp 127-135

223. Wood CD, Tiwari BN, Plumb VE, Powell CJ, Roberts BT, Sirimane VD, Rossiter JT, Gill M (1994) Interspecies differences and variability with time of protein precipitation activity of extractable tannins, crude protein, ash and dry matter contents 
of leaves from 13 species of Nepalese fodder trees. J Chem Ecol 20:3149-3162

224. Yeruham I, Avidar Y, Perl S, Yakobson B, Shlosberg A, Hanji V, Bogin E (1998) Probable toxicosis in cattle in Israel caused by the oak Quercus calliprinos. Vet Hum Toxicol 40:336-340

225. Yildiz S, Kaya I, Unal Y, Aksu Elmali D, Kaya S, Censiz M, Kaya M, Oncuer A (2005) Digestion and body weight change in Tuj lambs receiving oak (Quercus hartwissiana) leaves with and without PEG. Anim Feed Sci Technol 122:159-172

226. Yu F, Moughan PJ, Barry TN (1996) The effect of cottonseed condensed tannins on the ileal digestibility of amino acids in casein and cottonseed kernel. Br J Nutr 75:683-698
227. Yu F, Moughan PJ, Barry TN (1996) The effect of condensed tannins from heated and unheated cottonseed on the ileal digestibility of amino acids for the growing rat and pig. $\mathrm{Br} \mathbf{J}$ Nutr 76:359-371

228. Zhu J, Filippich LJ, Alsalami MT (1992) Tannic acid intoxication in sheep and mice. Res Vet Sci 53:280-292

229. Zombade SS, Lodhi GN, Ichhponani JS (1979) The nutritional value of salseed (Shorea robusta) meal for growing chicks. Br Poult Sci 20:433-438

230. Zimmer N, Cordesse R (1996) Digestibility and ruminal digestion of non-nitrogenous compounds in adult sheep and goats: effects of chestnut tannins. Anim Feed Sci Technol 61:259-273 